\title{
SELF-REFLEXIVE SCHEMATA OF EKPHRASIS IN COLLECTIONS OF ESSAYS ABOUT PAINTING: COGNITIVE AND LINGUISTIC ASPECTS
}

\author{
Tetyana Lunyova \\ $\mathrm{PhD}$, Postdoctoral Student, Kyiv National Linguistic University, Ukraine \\ e-mail: lunyovat@gmail.com,orcid.org/0000-0002-7022-0821
}

\section{Summary}

The aim of the paper is to reveal the cognitive structure and linguistic representation of self-reflexive schemata of ekphrasis construed in collections of essays about painting. The material of the study is six collections of essays written in English by modern authors. Conceptual semantic analysis, analysis in terms of conceptual metaphor, and contextual interpretative analysis have been applied in the study. The research has revealed the following tendencies in the construing of self-reflexive schemata of ekphrasis in collections of essays about painting: self-reflexive schemata of ekphrasis differ by their overall degree of self-reflexivity which correlates with the genre dominant of the texts where such schemata are objectified; the construing of the self-reflexive schemata of ekphrasis rely upon the basic cognitive processes of human thought; the knowledge about visual art which has been subjected to reflexion constitutes an important part of self-reflexive schemata of ekphrasis; self-reflexive schemata of ekphrasis contain specific concepts that are employed in the essays as the means of ekphrasis. Two types of instantiation of self-reflexive schemata of ekphrasis in the analysed collections of essays about painting have been detected: complete and partial instantiations. The notion of ekphrasis is linguistically objectified as the cognitive structure VERBAL REPRESENTATION OF VISUAL ART. Its component VERBAL REPRESENTATION can be actualised as a PROCESS and as a RESULT. The component VISUAL ART can be represented by the range of categories varying in their level of generalisation from high to low.

Keywords: visual, verbal, visual art, construing, metacognitive.

\section{DOI: https://doi.org/10.23856/3848}

\section{Introduction}

While grounded in the classical definitions of ekphrasis as "the literary representation of visual art" (Heffernan, 1991: 297) and "the verbal representation of visual representation" (Mitchell, 1994; Heffernan, 1996: 262), this study is a response to the "current expansion of ekphrasis" (Brosch, 2018: 225). In particular, drawing upon James Heffernan's note that ekphrasis "must also open itself up to the vast body of writing about pictures which is commonly known as art criticism" (1991: 304), this paper pursues the extension of ekphrasis along the line of "genres" (Brosch, 2018: 225). Thus the material of the study is the essays about painting as visual art written in English by modern authors (Barnes, 2015/2017; Berger, 2015; Bryson, 1990/2018; Hughes, 1987/1992; Hustvedt, 2005/2006; Writers on Artists, 2001). The relevance of this study is determined by its focus on the phenomenon of ekphrasis that has been exciting the growing interest of researchers. The methodology used in the research is the apparatus of cognitive linguistics and cognitive poetics, in particular, cognitive poetic studies of ekphrasis (Verdonk, 2005; Vorobyova, 2014; Izotova, 2018). The paper aspires to advance the understanding of the cognitive aspect of the interaction between the visual and the verbal in ekphrasis through the application of the new, cognitive linguistic and cognitive poetic 
approaches to ekphrasis in the essays about painting. Being briefly mentioned in several studies (Stoltzfus, 2011: 69; Brosch, 2018: 240), the self-reflexive aspect of ekphrasis has not received a thorough examination yet, hence the current study was designed to make a contribution to this research topic.

The aim of the research is to disclose the cognitive structure and examine verbal representation of self-reflexive schemata of ekphrasis in modern collections of essays about painting written in English.

The following tasks were set to achieve the aim of the study:

to reveal the regularities of the cognitive structuring of self-reflexive schemata of ekphrasis in collections of essays about painting;

to detect instantiations of self-reflexive schemata of ekphrasis in collections of essays about painting;

to determine the peculiarities of linguistic representation of self-reflexive schemata of ekphrasis in collections of essays about painting.

A range of methods has been applied in the study. Conceptual semantic analysis and analysis in terms of conceptual metaphor have been employed to reconstruct the conceptual structures objectified in the scrutinised essays. Contextual interpretative analysis has been applied to reconstruct the meanings construed in essays about painting.

\section{Regularities of the cognitive structuring of self-reflexive schemata of ekphrasis}

Schema is one of the terms used in cognitive sciences to designate "a means of representation of operational information" (Dem yankov, 1996: 179). It is characteristic of a schema to have a constant framework that is filled in with variables (op. cit.: 180).

The term self-reflexive as it is used in this paper is informed by the research on self-reflexive literature in literary studies and metacognition in cognitive psychology. The term self-reflexive "is applied to literary works that openly reflect upon their own processes of artful composition" (Oxford reference). This term describes "literary self-awareness" (Mambrol, 2019) or "text's consciousness of its own status" (Kao, 1997: 59). The term metacognition was introduced to describe the "knowledge and cognition about cognitive phenomena" (Flavell, 1979: 906); it "has been simply defined as thinking about thinking" (Nazarieh, 2016: 61).

In this study the term self-reflexive is applied to such contexts where an author of an essay (essays) about painting discusses the very nature of ekphrasis in the text (texts) collected in a book.

Self-reflexive schemata of ekphrasis are introduced in the Introductions to their collection of essays by Julian Barnes, Siri Hustvedt and Robert Hughes (Barnes, 2015/2017: 3-11; Hustvedt, 2005/2006: xv-xxi; Hughes, 1987/1992: 3-28), in the Preface by John Berger (Berger, 2015: $x i-x i i)$ and in the Foreword by Norman Bryson (Bryson, 1990/2018: 7-15). The collection of essays by different authors (Writers on Artists, 2001) includes the Foreword by A. S. Byatt (Byatt, 2001: 6) and the Introduction by Karen Wright (Wright, 2001: 7) which offer the self-reflexive schemata of ekphrasis. Overall, 7 texts which precede the essays about painting contain self-reflexive schemata of ekphrasis.

While the term ekphrasis is not used in either of the analysed collections of essays, the notion of ekphrasis is evoked when the cognitive structure VERBAL REPRESENTATION OF VISUAL ART is explicitly verbalised. For example, in his Introduction, Barnes notes: "I first began writing about art with a chapter on Géricault's Raft of the Medusa in my novel A History of the World in 101/2 Chapters (1989)." (Barnes, 2015/2017: 11). In the quoted passage 
the lexeme writing objectifies the cognitive structure VERBAL REPRESENTATION and the lexeme art, being semantically connected with the name of the picture Raft of the Medusa, objectifies the cognitive structure VISUAL ART. In a similar way the cognitive structure VERBAL REPRESENTATION OF VISUAL ART is actualised in the Foreword by Byatt: "Writing about painting is peculiarly difficult." (Byatt, 2001: 6).

A more detailed analysis of the verbal means of linguistic representation of self-reflexive schemata of ekphrasis is provided in Part 4 of this paper. This part discusses the regularities of the cognitive structuring of self-reflexive schemata of ekphrasis in collections of essays about painting.

Since the passages which represent self-reflexive schemata of ekphrasis are very closely semantically connected with the passages that represent the authors' theories of art, the later contexts were taken into consideration while modelling the self-reflexive schemata of ekphrasis.

The degree of self-reflexivity of the self-reflexive schemata of ekphrasis in the analysed material is different. The degree of self-reflexivity is comparatively low in the introduction/ preface/ foreword (henceforth the term introduction will be used for all chapters that precede the essays in the studied collections) when such an introduction is structured as a more or less detailed account of the personal experience of the author perceiving art. Such story-like introductions with self-reflexive schemata of ekphrasis with low degree of self-reflexivity are provided by Barnes (e.g., "I was once taken by my parents to the Wallace Collection in London: more gilt frames, and more unerotic nudes." (Barnes, 2015/2017: 4-6)), Berger (e.g., "Their inspiration has led me to write about art intermittently throughout my long life as a writer." (Berger, 2015: xi)), and Hustvedt (e.g., "Painting is there all at once. When I read a book, listen to music, or go to a movie, I experience these works over time." (Hustvedt, 2005/2006: xv)).

The degree of reflexivity is medium in the introductions which discuss the experience of writing about art in general terms which is provided by Byatt (e.g., "There are many ways of writing badly about painting.” (Byatt, 2001: 6)) and Wright (e.g., “... I was anguishing over the order of contents in this book, and at the risk of offending the more delicate egos of both writers and artists over their location in the book. David [David Sylvester] rebuked me: "There is only one solution," he said. "Place them chronologically, in the order of publication." (Wright, 2001: 7)). The same medium degree of reflexivity is characteristic of the introduction by Hughes that examines the tendencies in culture and art in the certain country at a given period (e.g., "It would be foolish to claim that 1945-70 in New York rivalled 1870-1914 in Paris." (Hughes, 1987/1992: 3)).

The degree of reflexivity is high in the introduction by Bryson who analyses the category "still life" as a category, i.e., a mental entity (e.g., "Still life as a category within art criticism is almost as old as still life painting itself." (Bryson, 1990/2018: 7).

While introductions differ by their overall degree of self-reflexivity, different parts of each introduction can also have various degrees of self-reflexivity. For example, in her Introduction, Hustvedt combines passages with lover degree of self-reflexivity (e.g., in the following passage Hustvedt writes about her experience rather than focusses on the content of her though "I love painting because in its immutable stillness it seems to exist outside time in a way no other art can." (Hustvedt, 2005/2006: xv)) and higher degree of self-reflexivity (e.g., in the following passage Hustvedt contemplates on the meaning of the category of picture: "Visual art exists only to be seen. It is the silent encounter between the viewer, "I", and the object, "it". That "it", however, is the material trace of another human consciousness." (Hustvedt, 2005/2006: xix)). 
The overall degree of self-reflexivity of the self-reflexive schemata of ekphrasis correlates with the genre dominant of the introductions. The introductions or those parts of the introductions that possess the features of fiction (mainly, the narrative structure) are characterised by the comparatively low degree of self-reflexivity (e.g., the narrative part of Berger's introduction (Berger, 2015: xi)). The introductions or those parts of the introductions that possess the features of journalism (mainly, the arguments criticising or praising some artistic practices) are characterised by the medium degree of self-reflexivity (e.g., Hughes's introduction (Hughes, 1987/1992: 3-28)). The high degree of self-reflexivity is typical of the introductions or those parts of the introductions which have the features of research writing (mainly, critical analysis of the approach and tools used for writing about art); it pertains to Bryson's introduction (Bryson, 1990/2018: 7-15).

Whereas all the self-reflexive schemata are unique in their cognitive structuring and linguistic representation, they exhibit a number of typical features pertaining to many of them or all of them.

The conceptual metaphor LEARNING SOMETHING IS MOVING SOMEWHERE has been used in 4 texts out of 7 (e.g., "I think of this book as a collection of mental peregrinations into the unknown." (Hustvedt, 2005/2006: xxi)). This regularity can be taken as an evidence of the fact that construing of the self-reflexive schemata of ekphrasis is grounded in the basic cognitive processes that characterise human thought.

The following conceptual structures are regularly objectified as well: TO LOOK AT VISUAL ART (7 texts out of 7) (e.g., "All of these writers share one vital quality, that of being visual: all of them relish the task of looking closely at art." (Wright, 2001: 7)), THE CONNECTION BETWEEN VISUAL ART AND LIFE (4 texts out of 7) (e.g., "Its goal [the goal of the book] is more practical: to try to develop the critical discourse around still life through a group of essays which engage with the paintings in the terms of our own time." (Bryson, 1990/2018: 10)), VISUAL ART CHANGES (3 texts out of 7) (e.g., "First there had been the Abstract Expressionists ... Then there were slightly younger painters whom Clement Greenberg and his school had nominated as the continuers of art history... And then the younger men and a few women..." (Hughes, 1987/1992: 3)); and the concept REVELATION (3 texts out of 7) (e.g., "These revelations have led me to conclude that those who analyse works of art for a living are not exempt from blind spots." (Hustvedt, 2005/2006: xix)). This regularity makes it plausible to assume that an important part of the self-reflexive schemata of ekphrasis is the knowledge about visual art which has been subjected to reflexion.

Almost every (6 out of 7) self-reflexive schema of ekphrasis contains specific concepts which have been selected by the authors as the means of ekphrasis. These concepts are different in different introductions. Barnes singled out the concepts ROMANTICISM, REALISM, MODERNISM: e.g., "But I found, when assembling these pieces, that I had unwittingly been retracing that story I tentatively started to read back in the 1960s: the story of how art (mainly French art) made its way from Romanticism to Realism and into Modernism." (Barnes, 2015/2017: 11). Berger selected the concepts HOPE, CHOICE, MISTAKE, DISCOVERY, e.g.: "And there I wait in the hope of learning something of the story of its [picture] making. Of the hopes, of the choices, of the mistakes, of the discoveries implicit in that story." (Berger, 2015: xi-xii). Bryson offered specific concepts for each of the four essays in his book: REALISM (realism), HYPER-REALISM (hyper-realism), SIMULATION (simulation), and POWER (power), which is specified as CLASS DIFFERENCE (class difference), CONTROL OVER NATURE (control over nature), and CONTROL OVER REPRESENTATION (control over representation) for the first essay (Bryson, 1990/2018: 15); UNIQUENESS 
(the exceptional act, the unique individual, personal uniqueness and distinction), GREATNESS ('greatness'), DAILY ROUTINE (the routines of daily life, the domestic round) for the second essay (Bryson, 1990/2018: 15); WEALTH (wealth), AFFLUENCE (affluence, plenty), MORALISM (moralism), VALUE (values) for the third essay (Bryson, 1990/2018: 15); and LOW-PLANE REALITY (low-plane reality), HIGH-PLANE REALITY (high-plane reality), GENDER POSITION (gender position), an GENDER IDEOLOGY (gender ideology) for the fourth essay (Bryson, 1990/2018: 15). Hustvedt gave special emphasis to the conceptual structure PICTURE DETAILS THAT HAVE NEVER BEEN NOTICED BEFORE, e.g.: “By looking long and hard and at every part of a picture, I've discovered elements that have never been discussed by art historians or critics before: an egg detail on the window frame of Vermeer's Woman with a Pearl Necklace [...] I also found several hidden self-portraits in Goya's Los Caprichos and one in The Third of May." (Hustvedt, 2005/2006: xviii-xix). Hughes employed the concepts CULTURAL COLONIALISM (e.g., "The essence of cultural colonialism is that you demand of yourself that your work measure up to standards that cannot be shared or debated where you live." (Hughes, 1987/ 1992: 4)) and IMPERIALISM OF THE MARKET (e.g., "This act of unwonted humility was made by thousands of people concerned with the making, distribution, teaching and judgment of art ... [...] The difference today is that instead of an imperialism of place we have an imperialism of the market, operating internationally." (Hughes, 1987/1992: 5-6). Byatt favoured the concepts TOUGHNESS (toughness), FLEXIBILLITY (flexibility), ACCURACY (accuracy), MODESTY (modesty), CURIOSITY (curiosity), and GENEROSITY (generosity), e.g.: "It isn't a text-book - the pieces are chosen primarily for the quality of the writing. And they have in common the virtues of toughness, flexibility, delight in impossible accuracy, writerly modesty - and above all, putting curiosity before the need to judge and generosity before smartness or position-taking." (Byatt, 2001: 6).

Among the listed above concepts only the concept REALISM is used by two authors Barnes and Bryson. However, different aspects of this concept are highlighted in the two contexts since Barnes puts REALISM in contrast with ROMANTICISM and MODERNISM while Bryson utilises REALISM in connection with HYPER-REALISM and SIMULATION.

\section{Instantiations of self-reflexive schemata of ekphrasis}

Every self-reflexive schema of ekphrasis construed in the introduction to the collection of essays about art is instantiated in the essays which follow. Within a particular instantiation either all the elements of a self-reflexive schema of ekphrasis are objectified or some of these elements. The first type of instantiation can be called complete instantiation and the second type can be termed partial instantiation.

The complete instantiation is regularly realised when the self-reflexive schema of ekphrasis is construed on the high level of generalisation (e.g. Wright's schema (Wright, 2001: 7) which can be modelled as the following structure WRITERS WHO WRITE ABOUT ART LIKE TO LOOK AT ART is realised in every single essay in the collection of essays (Writers on Artists, 2001)) or the author developed a specific self-reflexive schema of ekphrasis for each essay (e.g. Bryson's four specific schemata for his four essays (Bryson, 1990/2018: 15)).

A self-reflexive schema of ekphrasis which is construed on the level of specific information can also get a complete instantiation. For example, Hustvedt's self-reflexive schema of ekphrasis that can be modelled as the following structure TO WRITE ABOUT PAINTINGS WHICH ARE DIFFICULT TO UNDERSTAND AT ONCE IS TO MOVE SLOWLY TO THE KNOWLDEG ABOUT THESE PAINTINGS WITHOUT USING A PRECONCEIVED 
THEORETICAL FRAMEWORK WHICH LEADS TO DISCOVERY OF PICTURE DETAILS THAT HAVE NEVER BEEN NOTICED BEFORE AND TO REVELATION is completely realised in her essays “Vermeer's Annunciation" (Hustvedt, 2005/ 2006: 12-25) and "More Goya: “There Are No Rules in Painting”," (Hustvedt, 2005/ 2006: 93-119).

The partial instantiation takes place when some information presented in a self-reflexive schema of ekphrasis which is construed on the level of specific information gets actualised in a particular essay. For example, Barnes's self-reflexive schema of ekphrasis (Barnes, 2015/2017: 3-11) can be modelled as the five semantically connected cognitive structures: (1) VISUALART CHANGES FROM ROMANTICISM TO MODERNISM, (2) VISUAL ART CAN EXPRESS THE TRUTH, (3) VISUAL ART HAS THE PERIODS OF RE-EXAMINATION OF THE FORMS OF ART, (4) VISUAL ART IS THE IMPORTANT SOURCE OF KNOWLEDGE, (5) ART TRANSFORMS LIFE INTO SOMETHING RELATED TO LIFE BUT STRONGER, MORE INTENSE AND WEIRDER; in his essay "Delacroix: How Romantic?" (Barnes, 2015/2017: 42-57) cognitive structures (1), (3), (5) of this self-reflexive schema of ekphrasis are objectified.

On the one hand, partial instantiations of self-reflexive schemata of ekphrasis provide the solid cognitive foundation for the construing of new cognitive structures in the essays. For instance, the mentioned above essay about Delacroix's painting by Barnes contains the metaphoric structure ARTIST IS A CAT THAT KEEPS PERFECT BALANCE (e.g., "This is a literary equivalent of that catlike figure on the narrow pavement, keeping perfect balance. The critic comes to see the artist. [...] The critic leaves, and the artist goes back to his work..." (Barnes, 2015/2017: 54)). To give one more example of new cognitive structures being construed while some parts of a self-reflexive schema of ekphrasis are actualised, Berger's essay about Frida Kahlo's painting (Berger, 2015: 335-340) can be scrutinised. In this essay, the cognitive structures DOUBLE SENSITIVITY (e.g., "If this were to happen there would be a double sensitivity...” (Berger, 2015: 336)) and MEMORY OF THE SKIN (e.g., “... things which were already memories before they were painted memories of the skin." (Berger, 2015: 339)) are created while the concepts HOPE (e.g., "With her small brushes, fine as eyelashes, and with her meticulous strokes, every image she made, as soon as she fully became the painter Frida Kahlo, aspired to the sensibility of her own skin." (Berger, 2015: 336)) and CHOICE (e.g., "For her vision to remain intact, she needed to paint on a surface as smooth as skin." (Berger, 2015: 336)) that constitute the self-reflexive schema of ekphrasis construed by Berger (see Part 2 of this paper) are actualised.

On the other hand, partial instantiations of self-reflexive schemata of ekphrasis contribute to the uniqueness of each essay since various essays by the same author have different components of the self-reflexive schema actualised.

\section{Peculiarities of linguistic representation of self-reflexive schemata of ekphrasis}

As it has been noted above (see Part 2 of this paper), rather than employ the term ekphrasis, the authors of the analysed collections of essays use descriptive linguistic expressions that verbalise the cognitive structure VERBAL REPRESENTATION OF VISUAL ART (e.g., "Above all, he [Peter Fuller, the founder of the magazine Modern Painters] wished to make art writing both readable and enjoyable." (Wright, 2001: 7)). This regularity can be attributed to the communicative objective of the authors of the essays who hoped to reach a wide circle of readers and thus avoided using the term ekphrasis which is not widely used by common public. 
The component VERBAL REPRESENTATION of the cognitive structure VERBAL REPRESENTATION OF VISUALART can be actualised as a PROCESS (e.g., writing about art (Barnes, 2015/2017), Writing about painting (Byatt, 2001), to write - about art (Berger, 2015), write about art (Hustvedt, 2005/ 2006), discussion of painting (Bryson, 1990/2018)) and as a RESULT (e.g., art writing (Wright, 2001), book on still life painting (Bryson, 1990/2018), interpretation of still life у контексті з catalogues and monographs (Bryson, 1990/ 2018), book on Abstract Expressionism (Hughes, 1987/1992), claims made for any artist (Hughes, 1987/1992), discourses on how Newman's vertical zip was Adam (Hughes, 1987/1992)) depending on the aspect of ekphrasis which is highlighted by the author.

The component VISUAL ART of the cognitive structure VERBAL REPRESENTATION OF VISUAL ART can be represented by the range categories which vary in their level of generalisation from high (abstract categories) to low (concrete categories). As a result, the cognitive component VISUAL ART is represented by the category VISUAL ART which is characterised by the high level of generalisation (e.g., writing about art (Barnes, 2015/2017), to write - about art (Berger, 2015), write about art (Hustvedt, 2005/2006)), the category PAINTING which is more concrete than the category VISUAL ART (e.g., Writing about painting (Byatt, 2001), discussion of painting (Bryson, 1990/2018)), still more concrete categories STILL LIFE PAINTING (e.g., book on still life painting (Bryson, 1990/2018), interpretation of still life (Bryson, 1990/2018)) and ABSTRACT EXPRESSIONISM (e.g., book on Abstract Expressionism (Hughes, 1987/1992)) and even more concrete cognitive structures that represent the knowledge about pictures of several particular painters (e.g., claims made for any artist that Harold Rosenberg or Thomas Hess made for figures such as Barnett Newman and Willem de Kooning (Hughes, 1987/1992)) or one particular painter (e.g., discourses on how Newman's vertical zip was Adam, or the primal act of division of light from darkness, or the figure of the unnameable Yahweh himself (Hughes, 1987/1992)).

\section{Conclusions}

This research on self-reflexive schemata of ekphrasis in collections of essays about painting as visual art written by modern authors in English the has provided new insights into the cognitive and linguistic aspects of the phenomenon of ekphrasis through the study of the self-reflexive ekphrastic contexts, i.e. the contexts devoted by an author to the discussion of the very nature of ekphrasis as it is used in their essays about visual art. The study has revealed several tendencies in the construing of self-reflexive schemata of ekphrasis in collections of essays about painting: self-reflexive schemata of ekphrasis in different texts may be more or less self-reflexive depending on the genre dominant of the texts (research writing - journalism writing - fiction); the construing of the self-reflexive schemata of ekphrasis is grounded in the basic cognitive processes of human thought, in particular, conceptual metaphor is consistently employed; self-reflexive schemata of ekphrasis rely heavily upon the knowledge about visual art which has been subjected to reflexion; self-reflexive schemata of ekphrasis by different authors contain specific concepts which are employed in the essays as the means of ekphrasis. Besides, two types of instantiation of self-reflexive schemata of ekphrasis in collections of essays about painting have been identified: complete and partial. The partial instantiation provides the solid cognitive foundation for the construing of new cognitive structures in the essays and contributes to the uniqueness of each essay. Within the verbalisation of the cognitive structure VERBAL REPRESENTATION OF VISUAL ART its component VERBAL REPRESENTATION can be actualised as a PROCESS and as a RESULT. The component VISUAL ART 
can be represented by the range of categories that belong to different levels of generalisation from high (more abstract categories) to low (more concrete categories).

Overall, the construing and instantiation of self-reflexive schemata of ekphrasis in collections of essays about painting written by modern authors demonstrates the dymanics between generalisation and specification as the two leading cognitive processes the humans rely upon in their cognition of the world and interaction with it.

While this paper has exposed some important cognitive and linguistic aspects of self-reflexive schemata of ekphrasis in collections of essays about painting, a further research is needed to provide a deeper look into the functional aspect of such self-reflexive schemata of ekphrasis.

\section{References}

Barnes, J. (2015/2017). Keeping an Eye Open: Essays on Art. New York: Vintage International, Vintage Books. [in English].

Berger, J. (2015). Portraits: John Berger on artists / Ed. Tom Overton. London, New York: Verso. [in English].

Brosch, R. (2018). Ekphrasis in the Digital Age: Responses to Images. Poetics Today. 39 (2): 225-243. [in English].

Bryson, N. (1990/2018). Looking at the Overlooked: Four Essays on Still Life Painting. London: Reaktion Books [in English].

Byatt, A.S. (2001) Foreword. Writers on Artists. London, New York, Delhi, Sydney, Munich, Paris, Johannesburg: DK Publishing: 6. [in English].

Dem yankov, V. Z. (1996). Sxema. [Schema]. Kratkij slovar'kognitivny`x terminov / Kubryakova E. S., Dem yankov V. Z., Luzina L. G., Pankracz Yu. G. I pod obshhej redakciej E. S. Kubryakovoj. [A Brief Dictionary of Cognitive Terms / Ed. E. S. Kubryakova]. Moscow: Izdatel stvo Moskovskogo gosudarstvennogo universiteta: 179-181. [in Russian].

Flavell, J. H. (1979). Metacognition and cognitive monitoring: A new area of cognitive-development inquiry. Psychology. 34 (10): 906-911. [in English].

Heffernan, J. A. W. (1991). Ekphrasis and Representation. New Literary History. 22(2): 297-316. [in English].

Heffernan, J. A. W. (1996). Entering the Museum of Words: Browning's "My Last Duchess" and Twentieth-Century Ekphrasis. Icons - Texts - Iconotexts: Essays on Ekphrasis and Intermediality / Ed. By P. Wagner. Berlin, New York: de Gruyter \& Co: 262-280. [in English].

Hughes, R. (1987/1992). Nothing if not critical: selected essays on art and artists. New York: Penguin Books [in English].

Hustvedt, S. (2005/2006). Mysteries of the Rectangle: Essays on Painting. New York: Princeton Architectural Press. A Winterhouse ed. [in English].

Izotova, N. P. (2018). Ihrova stylistyka suchasnoho anhlomovnoho khudozhnoho naratyvu $v$ linhvistychnomu vysvitlenni (na materiali romaniv Dzh. M. Kutzee). Dysertatsiia na zdobuttia naukovoho stupenia doktora filolohichnykh nauk. Spetsialnist 10.02.04 - hermanski movy. Kyiv: Kyivskyi natsionalnyi linhvistychnyi universytet [Ludic stylistics of contemporary English fictional narrative from a linguistic perspective: A Study of J. M. Coetzee's novels. Thesis for the Doctor's degree in philology. Speciality 10.02.04 - Germanic languages. Kyiv: Kyiv National Linguistic University]. Kyiv. [in Ukrainian].

Kao, K. S. Y. (1997). Self-Reflexivity, Epistemology, and Rhetorical Figures. Chinese Literature: Essays, Articles, Reviews. 19: 59-83. [in English]. 
Mambrol, N. (2019). Self-reflexive Novels and Novelists. Available from: https://literariness.org/ 2019/03/19/self-reflexive-novels-and-novelists/ (Accessed on 24.07.2020) [in English].

Mitchell, W. J. T. (1994). Ekphrasis and the Other. Picture Theory. Chicago: The University of Chicago Press. Available from: http://www.rc.umd.edu/editions/shelley/medusa/mitchell.html (Accessed on 1.03.2018) [in English].

Nazarieh, M. (2016). A brief history of metacognition and principles of metacognitive instruction in learning. BEST: International Journal of Humanities, Arts, Medicine and Science. 2 (2): 61-64. [in English].

Oxford reference: self-reflexive Available from: https://www.oxfordreference.com/view/10.1093/ oi/authority.20110803100453429\#: : text =Quick\%20Reference,fictional\%20status\%20 (see\%20metafiction). (Accessed on 24.07.2020) [in English].

Stoltzfus, B. (2011) Ekphrasis in Magritte and Verne: Voyages extraordinaires to the Center of Art. The Comparatist. 35: 68-84. [in English].

Verdonk, P. (2005). Painting, poetry, parallelism : Ekphrasis, stylistics and cognitive poetics. Language and Literature. 14(3) August: 231-244. [in English]

Vorobyova, O. P. (2014). Multimodality of the real and virtual in Virginia Woolf's "A Simple melody". Cognitive and affective implications. Mova - literatura - mystetstvo: Kohnityvno-semiotychnyi interfeis: materialy bizhnarodnoi naukovoi konferentsii KNLU (25-27 veresnia 2014 r.) [Language - literature - the arts: A Cogntive-semiotic interface: International conference proceedings. KNLU (September 25-27, 2014)]. Ed. by O. P. Vorobyova. Kyiv: Vydavnychyy tsentr KNLU: 17. [in English].

Wright, K. (2001). Introduction. Writers on Artists. London, New York, Delhi, Sydney, Munich, Paris, Johannesburg: DK Publishing: 7. [in English].

Writers on Artists (2001). London, New York, Delhi, Sydney, Munich, Paris, Johannesburg: DK Publishing [in English]. 